Ośrodek Profilaktyki i Terapii Uzależnień w Gdyni

\title{
Pokolenie „always on” - psychologiczne i społeczne funkcjonowanie młodzieży korzystającej z nowych mediów
}

\section{Wstęp}

W przedmowie do swojej monografii Paul Levinson pisze o trafności nazwy cellphone:

Nie tylko przenosi się on [telefon komórkowy - przyp. aut.] z miejsca na miejsce, jak żywe komórki, lecz także, tak jak one, daje początek nowym wspólnotom, możliwościom i relacjom, gdziekolwiek zawita. [...] Cell to również cela. Telefon ten nie tylko otwiera nam nowe możliwości, ale i sprawia, że zawsze można się z nami połączyć. Tym samym więzi nas w nieustannej dostępności (Levinson 2006: 13).

Ten sugestywny opis idealnie oddaje cyfrowe czasy, w których obecnie żyjemy. Czasy pełne twórczej ekspresji na portalach, takich jak Instagram czy YouTube, a także nieskończonych możliwości kontaktu przez takie aplikacje jak Messenger, WhatsApp czy w końcu tradycyjne SMS-y. Stały kontakt stawia przed społeczeństwem zupełnie nowy typ wyzwania - bycie w ciągłej dostępności oraz aktywności technologicznej, które silnie angażują człowieka i zmienią jego codzienne funkcjonowanie. Z trudem radzi sobie z tym osoba już w pełni ukształtowana - tym bardziej trudne może okazać się to dla przeżywającego kryzysy emocjonalne adolescenta.

Po raz pierwszy terminu „cyfrowi tubylcy” (digital natives) użył Marc Prensky (2001). Określił tym mianem osoby urodzone po roku 1980, dla których komputer czy Internet są już nieodłącznym atrybutem codziennego funkcjonowania. Termin ten został zainspirowany określeniem native speakers, które oznacza osobę używającą języka ojczystego. Świat wirtualny jest więc dla cyfrowych tubylców w pewnym sensie "ojczyzną", którą dobrze znają i w której najlepiej się czują (Spitzer 2013). Określa się ich również mianem pokolenia always on czy także pokolenia Z. 
Komunikacja i funkcjonowanie społeczne młodzieży w świecie online

Według Prensky’ego otwartość i anonimowość w sieci znacząco zmieniają sposób myślenia młodych ludzi na temat kontaktów społecznych. W cień odchodzą interakcje analogowe (kontakty „na żywo”), które do tej pory charakteryzowała znaczna hierarchizacja i kontekst pełnionych ról społecznych czy miejsca, w jakim się one odbywały, na rzecz struktury chmurowej, w pełni demokratycznej, wielowątkowej i odbywającej się w nieokreślonym miejscu i czasie (Prensky 2012). Okazuje się jednak, że pokolenie Z prowadzi nad wyraz bogate życie społeczne, choć o zróżnicowanej jakości kontaktów. Jednoczesne budowanie odrębnych tożsamości na różnych portalach społecznościowych nie tylko pozwala im na ekspresję często sprzecznych ze sobą idei, którymi są zaabsorbowani, ale sprawia również, że ich sieć kontaktów staje się wyjątkowo szeroka i różnorodna. Często jednak nie potrafią oni poradzić sobie z tak ogromną grupą. Ponieważ w ich prywatnym, intymnym życiu mogą uczestniczyć wszyscy ci, którym udostępniają informacje o sobie i swojej codzienności, granica między tym, co prywatne, a tym, co publiczne, zaciera się.

$Z$ jednej strony mamy więc do czynienia z zachwianiem równowagi online-offline mogącej spłycać czy utrudniać koleżeńskie relacje, z drugiej zaś osoby, które do tej pory były raczej wykluczane z grupy rówieśniczej - z powodu niepełnosprawności, różnego rodzaju chorób, fobii społecznej lub zwyczajnej nieśmiałości - mogą nawiązać kontakty przy pomocy komunikacji online. Wirtualne grupy pozwalają im na budowanie więzi z osobami o podobnych zainteresowaniach (Filiciak et al. 2010). Może to pomóc tej części młodzieży przełamać się i ułatwić nawiązywanie kontaktów w świecie realnym (Young, Rodgers 1998).

Przeważenie szali kontaktów na stronę wirtualną może też być przyczyną zaburzeń relacji rodzinnych i społecznych. W 2012 roku ponad 1/3 polskich nastolatków deklarowała niekorzystny wpływ Internetu na relacje rodzinne i przyjacielskie (Rywczyńska 2012). Przyczyną może być tu nie tyle sama aktywność w sieci, ale proporcja kontaktów w świecie wirtualnym do tych w realnym, która $\mathrm{z}$ biegiem czasu przechyla się na stronę tego pierwszego. Barierą może okazać się też różnica wynikająca z obeznania rodziców czy opiekunów ze światem wirtualnym, co może pogłębiać przepaść dzielącą generacje.

Badania z początków popularyzacji Internetu donosiły, że korzystanie z niego wpływa na wzrost poczucia samotności (Kraut, Patterson, Lundmark et al. 1998). Z czasem jednak zaczęto zauważać, że wraz z rozwojem kompetencji posługiwania się tym wszechstronnym narzędziem symptomy te słabną (Kraut, Kiesler, Boneva et al. 2002), a poszerzony krąg znajomych podwyższa odczuwane społeczne wsparcie (Skarżyńska, Henne 2005). Dzieje się tak jednak tylko wtedy, gdy kontakty cyfrowe służą podtrzymywaniu realnych więzi w świecie rzeczywistym (Gross, Juvonen, Gable 2002). Wspomniane kontakty stają się wtedy uzupełnieniem tychże relacji oraz mogą być postrzegane jako jedna $z$ wielu form bycia razem i przeżywania wspólnych doświadczeń. 
Psychofizyczne konsekwencje nieprawidłowego korzystania z nowych technologii

Nadmierne korzystanie z nowych technologii nadwyręża funkcjonowanie układu mięśniowo-szkieletowego. Podczas używania smartfona przyjmujemy pozycję $\mathrm{z}$ głową skierowaną ku dołowi, co powoduje ból i wady postawy (Hansraj 2014). Zjawisko to otrzymało już własne nazwy: text neck (Hansraj 2014) czy turtle neck posture (Park et al. 2015). Nadwyrężenia również innych części ciała mogą prowadzić do poważnych schorzeń, takich jak: TOS, fibromialgia, syndrom de Quervaina (Yang et al. 2017; Sharan, Ajeesh 2012) czy zespół cieśni nadgarstka (Woronowicz 2009), szczególnie w czasie obsługiwania urządzenia jedną dłonią (Park et al. 2015).

Kolejnym ważnym problemem są zaburzenia snu wynikające z niewłaściwego korzystania z telefonów. Manfred Spitzer (2013) w swojej monografii wykazał, że używanie smartfonów bezpośrednio przed snem zaburza produkcję melatoniny, powoduje napięcia mięśniowe i pobudzenia oraz zmienia kontekst przestrzeni sypialni z relaksującego na aktywizujący. Zaburzenia snu z kolei niosą ze sobą wiele niepożądanych konsekwencji, począwszy od zwiększenia podatności na cukrzycę typu II, otyłość, problemy z przemianą materii, choroby układu sercowo-naczyniowego i nowotwory, przez obniżenie sprawności poznawczej i fizycznej, po nasilony stres, lęk, zaburzenia depresyjne czy nawet myśli samobójcze. Wynika $\mathrm{z}$ tego, że niewystarczające przygotowanie w obszarze odpowiedzialnego korzystania z technologii może przynosić mnogie i niekoniecznie pożądane skutki fizyczne i psychiczne.

Mózg z powodu ciągłego otoczenia technologią może wchodzić w stan długotrwałego rozkojarzenia. To zaś prowadzi do chronicznie podwyższonego poziomu stresu, co autorzy nazywają "technowypaleniem mózgu” (Small, Vorgan 2011). Jest on odczuwany zarówno poznawczo poprzez uczucie przebywania w „cyfrowej mgle", jak i biochemicznie - przez podwyższony poziom kortyzolu i adrenaliny (Small, Vorgan 2011).

Microsoft Kanada opublikował wyniki badań, które donoszą, że średni zakres uwagi między 2000 a 2013 rokiem zmniejszył się o ponad 30\%. Naukowcy wskazują również na problemy z selekcją informacji wywołane długotrwałym stanem wielozadaniowego odbierania bodźców, co powodowało, że badani nie byli w stanie ignorować nieistotnych bodźców rozpraszających (Gausby 2015).

Maria Ledzińska (2002) definiuje stres informacyjny jako zespół doznań towarzyszących niemożności bieżącego opracowania informacji oraz integrowania ich z dotychczasową wiedzą jednostki. Próbujący sobie z nim radzić człowiek może zastosować wiele strategii - aż po próbę całkowitego odcięcia się od świata zewnętrznego.

Czy jednak wpływ technologii orientuje się tylko wokół zagrożeń, ryzyka uzależnienia lub rozwoju - chociażby - nieprawidłowej postawy ciała? Zjawisko jej 
rozwoju jest o wiele bardziej rozbudowane i dotyczy także wpływów o zupełnie innym charakterze, zorientowanym między innymi na omawiane w dalszej części wsparcie społeczne, które - jak się okazuje - cechuje ciekawa niejednoznaczność.

\section{Wsparcie społeczne}

W badaniach nad korzystaniem z nowych technologii nie pomija się kontekstu odczuwania wsparcia społecznego. Helena Sęk podaje jego następujące kategorie (czy też wymiary):

- źródła wsparcia społecznego, w których skład wchodzą: wielkość sieci wsparcia, jej zasoby i dostępność;

- typy wsparcia: emocjonalne, informacyjne, instrumentalne, materialne oraz duchowe;

- wsparcie otrzymywane i spostrzegane;

- potrzeba oraz mobilizacja wsparcia (Sęk, Cieślak 2004).

Najistotniejszym wymiarem wsparcia jest jego dostępność. Nawet największa, najbardziej rozbudowana sieć społeczna nie zapewni jego odpowiedniego natężenia, jeśli pogłębiony kontakt z poszczególnymi członkami grupy będzie utrudniony. Taką złudną siecią okazują się grupy znajomych na portalach społecznościowych, których liczebność nie przekłada się na rzeczywiste odczuwanie korzyści emocjonalnych. Biorąc jednak pod uwagę różnorodność oczekiwanego wsparcia, można natknąć się na bardziej optymistyczne sytuacje - na przykład osoby z niepełnosprawnością poszukujące wsparcia informacyjnego na pewno skorzystają z internetowych grup samopomocowych, ponieważ dostępność ich członków oraz ich zasoby będą miały najwyższy poziom. Wskazuje to ciekawe zróżnicowanie w obszarze oczekiwań i możliwości - odbiorcy nie muszą bowiem oczekiwać nasilonej aktywności od osób, z którymi są w kontakcie na portalach społecznościowych. W tym samym czasie jednak osoby mające utrudniony dostęp do realizacji kontaktów międzyludzkich (niezależnie $\mathrm{z}$ jakiego powodu - chorobowego, geograficznego, wywołanego niepełnosprawnością itd.) zyskują potencjalne narzędzie komunikacyjne, oferujące przynajmniej częściowe zaspokojenie potrzeb czy indywidualnych celów społecznych.

Podział na wsparcie spostrzegane i otrzymywane jest wyjątkowo złożony. Oba rodzaje nie są bowiem zależne jedynie od obiektywnych przesłanek, ale również takich właściwości jednostki jak samoocena, pozycja społeczna, kompetencje czy poczucie kontroli. Łączą się one również z potrzebami. Otóż w zależności od nich różne osoby będą zadowalały się niższym lub wyższym obiektywnym poziomem wsparcia. Ci, którzy mają silną potrzebę niezależności i autonomii, będą przejawiać niższe nasilenie potrzeb wsparcia. Wyższą z kolei będą przejawiały jednostki niesamodzielne, o typie osobowości zależnej.

Jeszcze większe pogłębienie się niejednoznaczności oraz kompleksowości zjawiska przyniosła pandemia COVID-19. Praktykowanie społecznego dystansu poważnie 
wpłynęło na fizyczne spotkania, pozostawiając jednak możliwość wirtualnego spędzania czasu z drugim człowiekiem. To doprowadziło do ciekawej sytuacji, w której z jednej strony wymaga się od społeczeństwa uważnego i zbalansowanego korzystania z nowych technologii, realizacji pasji, wypoczynku, rozwoju kulturalnego poprzez nowe media, a z drugiej - ostrożności, dbałości o różnorodność bodźców, wysokiej samoregulacji podczas korzystania $\mathrm{z}$ technologii. Wsparcie społeczne $\mathrm{w}$ tym wymiarze także przenosi się coraz bardziej do przestrzeni wirtualnej.

\section{Jakość życia}

Wszystkie dotychczasowe rozważania mogą inspirować do refleksji - czy ogólna jakość życia młodych ludzi w zderzeniu z technologią zyskuje, czy traci? Czy pokolenie, którego centralnym punktem kontaktów społecznych był tzw. trzepak, odczuwała wyższy dobrostan niż młodzież, która zastąpiła go tablicą na "fejsie" czy ,insta”?

Zgodnie z definicją WHO jakość życia jest to „spostrzeganie przez jednostkę jej sytuacji życiowej w odniesieniu do kultury, w której ta jednostka żyje, jej systemu wartości, celów, oczekiwań, standardów i zainteresowań" (WHOQOL Group 1995). Jest ona uniwersalna z perspektywy międzykulturowej i międzypokoleniowej, stawia jednak akcent na aspekt subiektywny. Na poziom jakości życia składają się następujące obszary:

- fizyczny, obejmujący: doznania sensoryczne, ból, zmęczenie, sen i odpoczynek;

- psychiczny, w którego skład wchodzą: uczucia (pozytywne i negatywne), procesy poznawcze oraz samoocena;

- niezależności, która rozumiana jest jako: niezależność ruchowa, codzienna aktywność, zdolność porozumiewania się, uzależnienia;

- relacji społecznych, obejmujących: relacje osobiste, wsparcie społeczne (otrzymywane i dawane);

- środowiska, które tworzą: środowisko domowe, bezpieczeństwo i opieka, zasoby finansowe, wsparcie informacyjne, możliwość rekreacji, dostępność transportu. Definicja WHO została stworzona, by możliwe stało się ocenienie dobrostanu ludzi dorosłych, jednak można stosować ją również w odniesieniu do nastolatków. W latach 2001-2004 trzynaście współpracujących ze sobą krajów europejskich, w tym Polska, przeprowadziło badania dotyczące jakości życia zależnej od zdrowia (Robitail et al. 2006; Mazur et al. 2008). Opracowano model jakości życia uwzględniający:

- obszar fizyczny, obejmujący zdolność do aktywności fizycznej, objawy fizyczne oraz postawę wobec własnego zdrowia;

- obszar psychologiczny, obejmujący pozytywne i negatywne uczucia, samoocenę i obraz ciała oraz funkcjonowanie poznawcze; 
- obszar społeczny, obejmujący relacje rodzinne, funkcjonowanie w szkole oraz grupę rówieśniczą.

Ten model jakości życia zakładał dziesięć głównych sfer: samopoczucie fizyczne, psychiczne, nastroje i emocje, obraz samego siebie, niezależność, relacje z rodzicami i życie w domu, zasoby finansowe, wsparcie społeczne i rówieśnicy, środowisko szkolne oraz akceptacja/odrzucenie społeczne (Robitail et al. 2006).

\section{Uzależnienie i problemowe korzystanie z telefonów komórkowych}

Badacze z Chin jako pierwsi zauważyli problem i zastosowali termin „syndrom nadmiernej zależności od telefonu komórkowego" (Jarczyńska 2014: 130). Autorzy wskazywali, że objawia się on między innymi: potrzebą posiadania telefonu stale przy sobie, wyczekiwaniem połączenia czy wiadomości tekstowej, kompulsywnym sprawdzaniem ekranu telefonu oraz odczuwaniem ciągłego niepokoju w przypadku jego braku, co prowadzi do zaburzeń snu i agresji.

Współcześnie uzależnienie od telefonu komórkowego określa się jako nieprawidłowy, dysfunkcjonalny sposób korzystania z niego. Aby jednak zdiagnozować uzależnienie u danej osoby, musi u niej w przeciągu ostatnich dwunastu miesięcy wystąpić co najmniej pięć spośród wymienionych objawów:

- silne pragnienie korzystania z telefonu komórkowego, prowadzenia rozmów czy wysyłania SMS-ów, wyrażone stałym myśleniem o wymienionych czynnościach,

- potrzeba zwiększania częstotliwości i czasu rozmów telefonicznych oraz zwiększania liczby i częstości wysyłania SMS-ów,

- powtarzające się nieskuteczne próby zaprzestania lub ograniczenia liczby rozmów i wysyłanych wiadomości SMS,

- występowanie objawów abstynencyjnych, takich jak: niepokój, lęk, depresja podczas prób zaprzestania lub redukowania liczby i czasu rozmów przez komórkę oraz liczby wysyłanych SMS-ów,

- prowadzenie dłuższych rozmów i wysyłanie większej liczby SMS-ów niż się uprzednio planowało,

- problemy finansowe, zawodowe, rodzinne i społeczne spowodowane korzystaniem z telefonu komórkowego,

- okłamywanie rodziny i znajomych w celu ukrycia kosztów oraz czasu poświęconego na rozmowy telefoniczne i wysyłanie SMS-ów,

- używanie telefonu komórkowego jako ucieczki przed prawdziwymi problemami lub w celu poprawienia złego samopoczucia (osamotnienia, niepokoju, depresji, winy) (Pawłowska, Potembska 2011: 443).

Można również zaobserwować takie sygnały ostrzegawcze, jak częste myśli o telefonie oraz złe samopoczucie i trudności ze skupieniem uwagi w sytuacji jego braku, przekraczanie wyznaczonego abonamentu, nieudane próby ograniczenia korzystania $\mathrm{z}$ telefonu pomimo widocznych negatywnych konsekwencji związanych z jego nadużywaniem oraz okłamywanie otoczenia i alienacja. Niepokojące 
może być również zbyt duże przywiązywanie wagi do wartości własnego telefonu i posiadanie więcej niż jednego aparatu.

Zdiagnozowanie uzależnienia może przeprowadzić wyłącznie osoba odpowiednio do tego przygotowana (psychiatra, psychoterapeuta, osoba mająca odpowiednie uprawnienia). Tylko specjalista będzie w stanie skonstruować odpowiedni plan działania mający na celu poprawę stanu osoby znajdującej się w zagrożeniu uzależnieniem bądź ryzykownym korzystaniu z technologii

Osobę, która przejawia zachowania typowe dla uzależnienia, nie otrzymała jednak profesjonalnej diagnozy lub nie spełnia jeszcze w pełni jej kryteriów, można określić jako „ryzykownie używającą".

Metodologia badań własnych

W niniejszej części przedstawię metodologię badań własnych, która pozwoliła ukształtować, zebrać oraz dokonać analizy danych.

\section{Charakterystyka grupy badanej}

W badaniu łącznie wzięły udział 453 osoby. Respondenci uczęszczali do szkół średnich: I Liceum Ogólnokształcącego oraz Zespołu Szkół nr 2 (klasy technikum) w Mrągowie (województwo warmińsko-mazurskie), Centrum Kształcenia Zawodowego i Ustawicznego nr 1 (klasy technikum i zawodowe) oraz Zespołu Szkół Hotelarsko-Gastronomicznych (klasy technikum) w Gdyni i I Liceum Ogólnokształcącego w Rumii (województwo pomorskie). Najliczniejszą grupę stanowily osoby w wieku 16 lat $(49 \%$ [ $\mathrm{N}=222])$ oraz kolejno: 17 lat $(28,48 \%$ [ $\mathrm{N}=129]), 18$ lat $(21,19 \%$ $[\mathrm{N}=96])$ i 19 lat $(1,32 \%$ [N = 6]), ucząca się w technikach $(60,71 \%$ [ $=275])$, liceach ogólnokształcących $(29,58 \%$ [ $\mathrm{N}=134])$ oraz szkołach zawodowych $(9,71 \%$ [N = 44]). Wśród badanych 222 osoby to dziewczęta (49\%), a 231 to chłopcy (51\%). W przypadku osób poniżej 18. roku życia uzyskano zgodę opiekunów prawnych.

W drugim etapie badania uczestniczyło 186 osób, które ukończyły etap pierwszy oraz poprawnie zainstalowały i skonfigurowały aplikację.

Badanie zostało zakończone w maju 2018 roku.

\section{Opis metod badawczych}

W badaniu wykorzystano poniższe metody badawcze:

- kwestionariusz KIDSCREEN Health - related Quality of Life Screening Instrument for Children and Adolescents (Mazur et al. 2008) - posłużył do zbadania jakości życia. Jest to skrócona wersja kwestionariusza KIDSCREEN-52, obejmująca pięć obszarów składających się na profil jakości życia: samopoczucie fizyczne, samopoczucie psychiczne, niezależność i rodzice, wsparcie społeczne 
oraz koledzy i środowisko szkolne. Zakres współczynników a-Cronbacha dla wymiarów cząstkowych znajduje się pomiędzy 0,791 a 0,878;

- kwestionariusz Berlińskich Skal Wsparcia Społecznego (BSSS): w celu zbadania wsparcia społecznego wykorzystano jego polską adaptację autorstwa Łuszczyńskiej, Kowalskiej, Schwarzera i Szulz (2002). Za pomocą kwestionariusza badane są poznawcze i behawioralne wymiary wsparcia społecznego. Pełny kwestionariusz składa się z pięciu niezależnych skal: dostępnego wsparcia, zapotrzebowania na wsparcie, poszukiwanego wsparcia, aktualnie otrzymywanego wsparcia oraz wsparcia ochronnego. W badaniu została wykorzystana część A, złożona z trzech pierwszych skal. Wartość współczynnika zgodności wewnętrznej a-Cronbacha dla tej skali wynosi 0,8 (Łuszczyńska et al. 2006);

- ankieta fonoholizmu - do zbadania nałogowego korzystania z telefonu komórkowego wykorzystano wersję skonstruowaną przez Dębskiego, Radziwiłłowicz i Kozłowską-Frąk (2018). Bada ona osiem symptomów nałogowego korzystania ze smartfona: nierozstawanie się z telefonem, bycie w ciągłej gotowości na kontakt, przeżywanie określonych stanów emocjonalnych, zmęczenie fizyczne, zaniedbywanie obowiązków, chęć odpoczynku i bycia offline, własna ocena nałogowego korzystania, własna ocena realnych i negatywnych skutków. Wartość współczynnika zgodności wewnętrznej a-Cronbacha dla tej skali wynosi 0,903 (Dębski 2016);

- aplikacja Quality Time, dostępna w systemie Android: użyto jej do zbadania realnego czasu spędzanego przed ekranem smartfona. Aplikacja ta za zgodą użytkownika mierzy czas korzystania z aplikacji mobilnych.

\section{Pytania badawcze}

Sformułowano następujące pytania badawcze:

- Czy młodzież trafnie przewiduje czas spędzany przed ekranem telefonu komórkowego?

- Czy istnieje - a jeżeli tak, to jaki - związek pomiędzy rzeczywistym czasem korzystania ze smartfona a subiektywną oceną jego trwania?

- Czy istnieje - a jeżeli tak, to jaki - związek pomiędzy jakością życia młodzieży a ryzykownym użytkowaniem telefonu komórkowego?

- Czy istnieje - a jeżeli tak, to jaki - związek pomiędzy doświadczanym przez młodzież wsparciem społecznym a ryzykownym użytkowaniem telefonu komórkowego?

- Które spośród wszystkich badanych zmiennych są najsilniejszymi predyktorami ryzykownego użytkowania telefonu komórkowego? 


\section{Wyniki}

Biorąc pod uwagę zebrane materiały oraz ich analizy, wyniki można podzielić na następujące obszary: wsparcie społeczne, jakość życia, możliwe uzależnienie od smartfona, związek pomiędzy możliwym uzależnieniem a zmiennymi oraz wpływ badanych zmiennych na możliwe uzależnienie.

\section{Wsparcie społeczne}

W przeprowadzonym badaniu średni wynik skali BSSS uzyskany wśród młodzieży wynosi 50,82 (SD = 9,12). Narzędzie nie dysponuje normami dla populacji, można jednak określić ten wynik jako wysoki (maksymalna możliwa liczba punktów wynosiła 68 punktów).

Średnie otrzymywanie wsparcie emocjonalne wyniosło 13,28 (SD = 2,53) (wynik maksymalny to 16 punktów), instrumentalne - 13,60 (SD = 2,67) (wynik maksymalny to 16 punktów), poszukiwanie wsparcia - 13,02 ( $\mathrm{SD}=3,73$ ) (wynik maksymalny to 20 punktów), zaś zapotrzebowanie na wsparcie - 10,79 $(\mathrm{SD}=2,86)$ (wynik maksymalny to 16 punktów).

Z danych wynika, że 24,4\% młodzieży jest niezadowolonych z ogólnego poziomu wsparcia społecznego w swoim życiu. W przypadku otrzymywania wparcia emocjonalnego jest to 9,3\%, a instrumentalnego jedynie 5,3\%. 21\% badanych deklaruje, że nie potrzebuje wsparcia społecznego, zaś $26,2 \%$ twierdzi, że go nie poszukuje.

\section{Jakość życia}

Badanie wykazało, że średnie wyniki podskal są zbliżone do norm krajowych (różnice nie były istotne statystycznie), opracowanych dla młodzieży w wieku 15-18 lat.

Tabela 1. Jakość życia - wyniki znormalizowane oraz otrzymane w badanej grupie

\begin{tabular}{|c|c|c|c|c|}
\hline \multirow{2}{*}{ Zmienne } & \multicolumn{2}{|c|}{$\begin{array}{l}\text { Wyniki otrzymane w badanej } \\
\text { próbie }\end{array}$} & \multicolumn{2}{|c|}{ Normy } \\
\hline & Średnia & $\begin{array}{l}\text { Odchylenie } \\
\text { standardowe }\end{array}$ & Średnia & $\begin{array}{l}\text { Odchylenie } \\
\text { standardowe }\end{array}$ \\
\hline Zdrowie fizyczne & 61,93 & 21,66 & 62,60 & 18,05 \\
\hline Samopoczucie psychiczne & 61,14 & 20,93 & 65,24 & 17,66 \\
\hline Niezależność i relacje z rodzicami & 61,25 & 19,29 & 58,44 & 18,81 \\
\hline Rówieśnicy i wsparcie społeczne & 64,16 & 22,84 & 61,47 & 19,69 \\
\hline Środowisko szkolne & 56,04 & 20,26 & 53,30 & 17,68 \\
\hline
\end{tabular}

Źródło: opracowanie własne. 
Czas spędzany przed ekranem smartfona

i deklarowany czas użytkowania urządzenia

W drugim etapie badań wzięło udział 181 osób, w tym 86 dziewcząt (47,5\%) i 95 chłopców (52,5\%).

Badani, którzy uczestniczyli w obu pomiarach, deklarują, że spędzają przed ekranem smartfona średnio $6 \mathrm{~h} 1 \mathrm{~min}(\mathrm{M}=6,02, \mathrm{SD}=3,96)$. Najwyższą deklarowaną wartością było $18 \mathrm{~h}$, którą wskazały 4 osoby (2,2\%), najmniejszą zaś 30 min, którą wskazały 2 osoby $(1,1 \%)$.

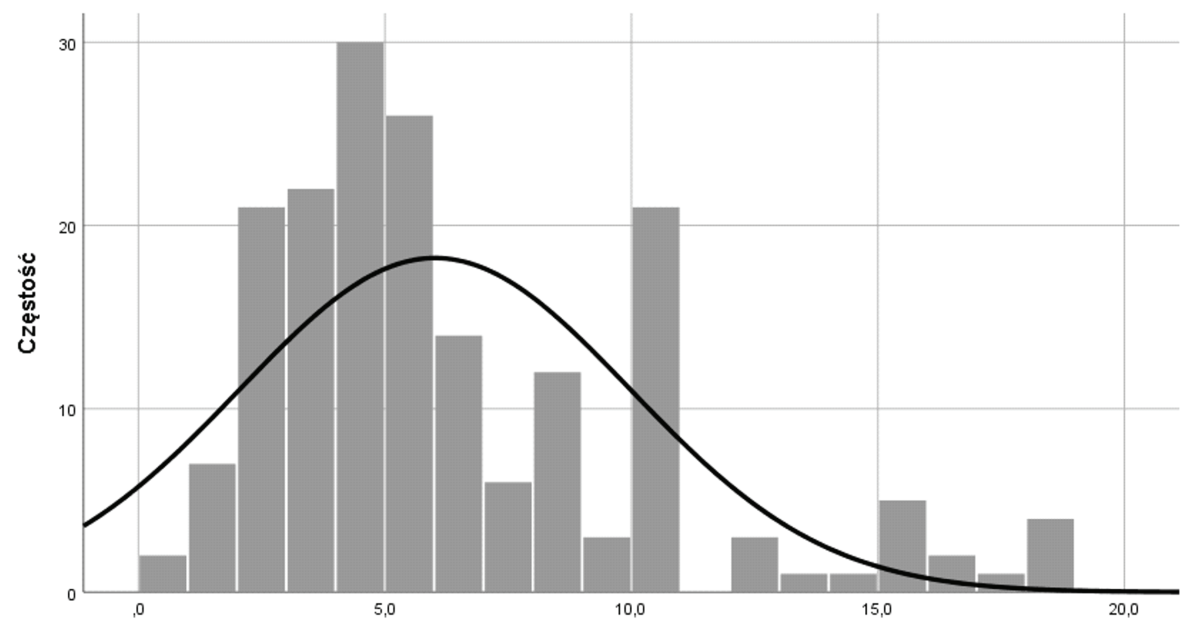

Czas korzystania

Wykres 1. Rozkład czasu deklarowanego użytkowania smartfona w badanej grupie

Źródło: opracowanie własne.

Z pomiarów dokonanych za pomocą aplikacji wynika, że badana młodzież spędzała przed ekranem telefonu średnio $3 \mathrm{~h} 38 \mathrm{~min}(\mathrm{M}=3,63, \mathrm{SD}=1,84) .8,3 \%$ respondentów użytkowało telefon mniej niż godzinę, zaś 3,3\% robiło to ponad 7. Najwyższy wynik wynosił 8 h $53 \mathrm{~min}$. 


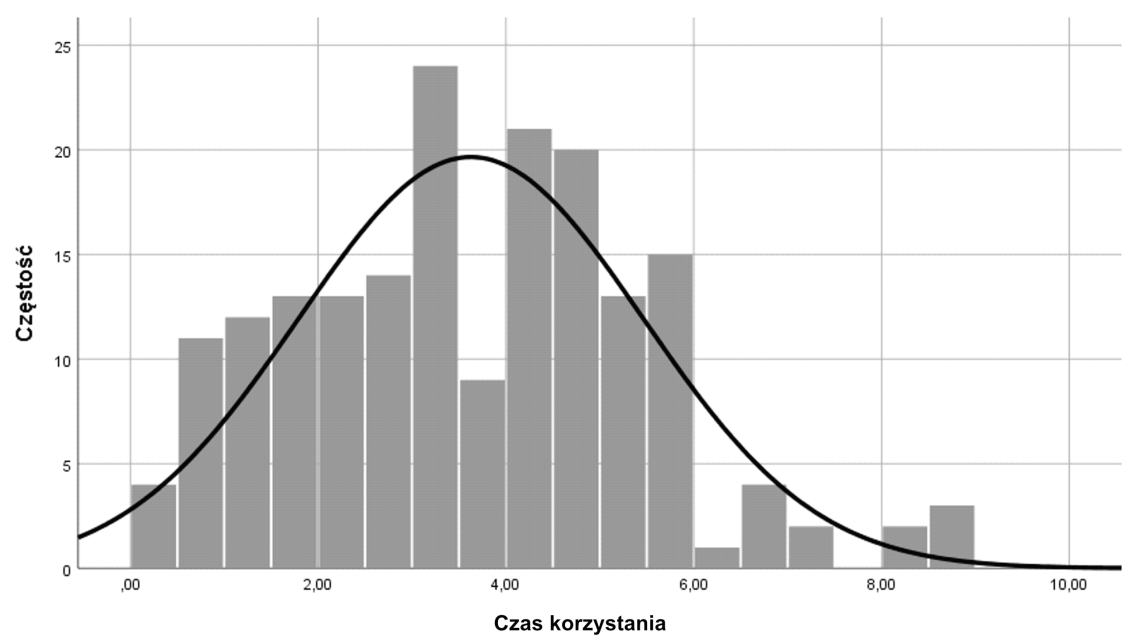

Wykres 2. Rozkład czasu użytkowania smartfona w badanej grupie Źródło: opracowanie własne.

Chłopcy $(\mathrm{M}=4,87, \mathrm{SD}=3,47)$ deklarują, że przed ekranem spędzają średnio o 1 h 57 min mniej niż dziewczęta $(M=7,28, S D=4,11)$. Jednak w realnym czasie spędzanym na użytkowaniu smartfona nie ma pomiędzy nimi istotnych różnic (średnia dla dziewcząt wynosi 3 h 46 min [SD = 1,68], dla chłopców 3 h 30 min [SD = 1,97]).

Ze względu na rozkłady wyników, które nie spełniały cech rozkładu normalnego, wykonano analizę korelacji Spearmana. Wykazała ona, że obie zmienne - czas deklarowany i realny - są umiarkowanie skorelowane ( $r h o=0,30, p<0,01$ ).

Średnia różnica pomiędzy czasem deklarowanym a realnie spędzanym przed ekranem smartfona wynosiła 2 h 23 min (SD = 3,93). 69,6\% młodzieży zadeklarowała, że spędza więcej czasu przy telefonie niż wynika to z pomiaru. Średnia różnica czasów osób, które zadeklarowały wyższy wynik niż realnie mierzony aplikacją, wyniosła 3 h 55 min $(S D=3,58)$, czyli o 1 h 32 min więcej niż średnia różnica w całej grupie. Dodatkowo analizy korelacji Spearmana wykazały, że realnie spędzany czas oraz wyżej opisana różnica wykazują słabą, lecz istotną korelację ujemną (rho $=-0,28, \mathrm{p}<0,01)$, zaś deklarowany czas oraz różnica czasów wykazują bardzo silną korelację dodatnią (rho = 0,79, p < 0,01).

Z powyższych danych można wnioskować, że większość młodzieży ma poczucie, że poświęca na tę aktywność znacznie więcej czasu niż w rzeczywistości. Zawyżanie tego czasu nie idzie jednak w parze ze wzrostem czasu realnie spędzanego przy urząadzeniu. Zależność ta jest wręcz odwrotna - im mniej czasu badany poświęca na korzystanie ze smartfona, tym wyżej go przeszacowuje. Jednak im wyższy wynik podaje badany, tym większe prawdopodobieństwo, że jego szacunki nie mają odzwierciedlenia w realnym pomiarze. 


\section{Uzależnienie od smartfona}

W przeprowadzonym badaniu średni wynik skali fonoholizmu uzyskany wśród młodzieży wynosi $69,86(\mathrm{SD}=12,12)$. Narzędzie nie posiada norm dla populacji, można jednak określić ten wynik jako przeciętny (maksymalna możliwa liczba punktów wynosi 116).

\section{Związek pomiędzy uzależnieniem od smartfona a badanymi zmiennymi}

W celu odpowiedzi na pytanie badawcze, czy istnieje związek pomiędzy jakością życia młodzieży, wsparciem społecznym oraz czasem użytkowania urządzenia a ryzykownym użytkowaniem telefonu komórkowego, przeprowadzono analizę korelacji pomiędzy zmienną uzależnienie od smartfona a zmiennymi: realnym i deklarowanym czasem użytkowania smartfona, wsparciem społecznym i jakością życia oraz podskalami tych zmiennych. Ze względu na niespełnianie cech rozkładu normalnego przez niektóre zmienne przeprowadzono analizę korelacji Spearmana. Jej wyniki przedstawiono w tabeli 2.

Tabela 2. Związek pomiędzy uzależnieniem od telefonu komórkowego a wsparciem społecznym, jakością życia oraz deklarowanym i realnym czasem użytkowania smartfona

\begin{tabular}{|c|c|c|c|c|}
\hline $\mathrm{Zn}$ & nne & $\begin{array}{l}\text { Uzależnienie } \\
\text { od smartfona }\end{array}$ & $\begin{array}{c}\text { Deklarowany } \\
\text { czas } \\
\text { użytkowania }\end{array}$ & $\begin{array}{l}\text { Realny czas } \\
\text { użytkowania }\end{array}$ \\
\hline & Współczynnik korelacji & $0,449^{* *}$ & . & $0,317^{* *}$ \\
\hline $\begin{array}{l}\text { Deklarowany czas } \\
\text { użytkowania smartfona }\end{array}$ & Istotność (dwustronna) & 0,000 & . & 0,000 \\
\hline & $\mathrm{N}$ & 447 & 450 & 181 \\
\hline & Współczynnik korelacji & $0,301^{* *}$ & $0,317^{* *}$ & . \\
\hline $\begin{array}{l}\text { Realny czas uzytkowania } \\
\text { smartfona }\end{array}$ & Istotność (dwustronna) & 0,000 & 0,000 & . \\
\hline & $\mathrm{N}$ & 182 & 183 & 181 \\
\hline & Współczynnik korelacji & $0,341^{* *}$ & $0,172^{* *}$ & 0,102 \\
\hline Wsparcie społeczne & Istotność (dwustronna) & 0,000 & 0,000 & 0,167 \\
\hline & $\mathrm{N}$ & 448 & 448 & 181 \\
\hline & Współczynnik korelacji & $0,148^{* *}$ & $0,153^{* *}$ & 0,128 \\
\hline Wsparcie emocjonalne & Istotność (dwustronna) & 0,002 & 0,001 & 0,084 \\
\hline & $\mathrm{N}$ & 448 & 448 & 181 \\
\hline & Współczynnik korelacji & $0,124^{* *}$ & $0,164^{* *}$ & $0,192^{* *}$ \\
\hline $\begin{array}{l}\text { W sparcie } \\
\text { instrumentalne }\end{array}$ & Istotność (dwustronna) & 0,009 & 0,000 & 0,009 \\
\hline & $\mathrm{N}$ & 448 & 448 & 181 \\
\hline
\end{tabular}




\begin{tabular}{|c|c|c|c|c|}
\hline \multicolumn{2}{|c|}{ Zmienne } & \multirow{2}{*}{$\begin{array}{l}\text { Uzależnienie } \\
\text { od smartfona } \\
\mathbf{0 , 4 0 2}^{* *}\end{array}$} & \multirow{2}{*}{$\begin{array}{c}\text { Deklarowany } \\
\text { czas } \\
\text { użytkowania } \\
\text { smartfona }\end{array}$} & \multirow{2}{*}{$\begin{array}{c}\begin{array}{c}\text { Realny czas } \\
\text { użytkowania } \\
\text { smartfona }\end{array} \\
0,113\end{array}$} \\
\hline & Współczynnik korelacji & & & \\
\hline $\begin{array}{l}\text { Zapotrzebowanie } \\
\text { na wsparcie }\end{array}$ & Istotność (dwustronna) & 0,000 & 0,000 & 0,127 \\
\hline & $\mathrm{N}$ & 448 & 448 & 181 \\
\hline \multirow{3}{*}{ Poszukiwanie wsparcia } & Współczynnik korelacji & $0,340^{* *}$ & 0,089 & 0,018 \\
\hline & Istotność (dwustronna) & 0,000 & 0,061 & 0,804 \\
\hline & $\mathrm{N}$ & 448 & 448 & 181 \\
\hline \multirow{3}{*}{ Zdrowie fizyczne } & Współczynnik korelacji & $-0,058$ & $-0,034$ & $-0,048$ \\
\hline & Istotność (dwustronna) & 0,218 & 0,472 & 0,517 \\
\hline & $\mathrm{N}$ & 447 & 447 & 181 \\
\hline \multirow{3}{*}{$\begin{array}{l}\text { Samopoczucie } \\
\text { psychiczne }\end{array}$} & Współczynnik korelacji & $0,163^{* *}$ & 0,074 & $0,146^{*}$ \\
\hline & Istotność (dwustronna) & 0,001 & 0,117 & 0,050 \\
\hline & $\mathrm{N}$ & 447 & 447 & 181 \\
\hline \multirow{3}{*}{$\begin{array}{l}\text { Niezależność } \\
\text { i relacje z rodzicami }\end{array}$} & Współczynnik korelacji & $-0,105^{*}$ & $-0,108^{*}$ & $-0,074$ \\
\hline & Istotność (dwustronna) & 0,026 & 0,022 & 0,320 \\
\hline & $\mathrm{N}$ & 447 & 447 & 181 \\
\hline \multirow{3}{*}{$\begin{array}{l}\text { Rówieśnicy i wsparcie } \\
\text { społeczne }\end{array}$} & Współczynnik korelacji & $0,149^{* *}$ & $0,137^{* *}$ & 0,040 \\
\hline & Istotność (dwustronna) & 0,002 & 0,004 & 0,595 \\
\hline & $\mathrm{N}$ & 447 & 447 & 181 \\
\hline \multirow{3}{*}{$\begin{array}{l}\text { Środowisko szkolne } \\
\text { i nauka }\end{array}$} & Współczynnik korelacji & $-0,217^{* *}$ & $-0,153^{\star *}$ & 0,002 \\
\hline & Istotność (dwustronna) & 0,000 &, 001 & 0,977 \\
\hline & $\mathrm{N}$ & 447 & 447 & 181 \\
\hline $\begin{array}{l}{ }^{*} \text { Korelacja istotna na pc } \\
{ }_{* *} \text { Korelacja istotna na p }\end{array}$ & $\begin{array}{l}\text { nie } 0,05 \text { (dwustronnie). } \\
\text { mie } 0,01 \text { (dwustronnie). }\end{array}$ & & & \\
\hline
\end{tabular}

Źródło: opracowanie własne.

W przypadku zmiennej uzależnienia od smartfona najsilniejsze w kolejności korelacje zaobserwowano ze zmiennymi: deklarowanym czasem użytkowania urządzenia $($ rho $=0,45, p<0,01)$, zapotrzebowaniem na wsparcie $(r h o=0,40, p<0,01)$, ogólnym wskaźnikiem wsparcia społecznego $(\mathrm{rho}=0,34, \mathrm{p}<0,01)$, poszukiwaniem wsparcia $($ rho $=0,34, \mathrm{p}<0,01)$ oraz realnym czasem spędzanym przed ekranem $(\mathrm{rho}=0,30, \mathrm{p}<0,01)$. Istnieje również słabszy związek pomiędzy fonoholizmem a środowiskiem szkolnym ( $r h o=-0,22, \mathrm{p}<0,01)$, samopoczuciem emocjonalnym ( $\mathrm{rho}=0,16, \mathrm{p}<0,01$ ), wsparciem emocjonalnym $(\mathrm{rho}=0,15, \mathrm{p}<0,01)$, wsparciem instrumentalnym $(\mathrm{rho}=0,12, \mathrm{p}<0,01)$ oraz niezależnością i relacjami $\mathrm{z}$ rodzicami $($ rho $=0,11, \mathrm{p}<0,05)$. 
Deklarowany czas korzystania ze smartfona istotnie - choć słabo - koreluje z następującymi zmiennymi: ogólnym wskaźnikiem wsparcia społecznego $(\mathrm{rho}=0,17, \mathrm{p}<0,01)$, zapotrzebowaniem na wsparcie ( $\mathrm{rho}=0,17, \mathrm{p}<0,01)$, wsparciem instrumentalnym $(\mathrm{rho}=0,16, \mathrm{p}<0,01) \mathrm{i}$ emocjonalnym $(\mathrm{rho}=0,15$, $\mathrm{p}<0,01$ ), środowiskiem szkolnym $(\mathrm{rho}=-0,15, \mathrm{p}<0,01$ ) oraz niezależnością i relacjami $\mathrm{z}$ rodzicami $(\mathrm{rho}=0,11, \mathrm{p}<0,05)$.

Czas realnie spędzany przed urządzeniem koreluje słabo ze wsparciem instrumentalnym ( $(\mathrm{hho}=0,19, \mathrm{p}<0,01)$ oraz samopoczuciem psychicznym (rho $=0,15$, $\mathrm{p}<0,05)$.

Wynika z tego, że deklarowany czas jest lepszym predyktorem uzależnienia od smartfona niż czas realnie poświęcany na taką aktywność. Z kolei komponenty zapotrzebowania na wsparcie i poszukiwania go mają większy związek z uzależnieniem niż samo odczuwane wsparcie (zarówno emocjonalne, jak i instrumentalne) oraz wyższy niż spostrzegana jakość życia. Co zastanawiające, większość korelacji (poza samopoczuciem w szkole) jest dodatnia, a więc można by przyjąć, że wraz ze wzrostem badanych wskaźników zmiennych rośnie również prezentowany poziom uzależnienia.

Wpływ badanych zmiennych na uzależnienie od smartfona

Ostatnią częścią analizy statystycznej była analiza regresji liniowej, przeprowadzona w celu ustalenia, które spośród wszystkich badanych zmiennych są predyktorami uzależnienia od smartfona. Wyniki znajdują się w tabeli 3.

Tabela 3. Predyktory uzależnienia od telefonu komórkowego

\begin{tabular}{|c|c|c|c|c|c|}
\hline Zmienna wyjaśniająca & $\mathrm{R}$ & $\mathrm{R}^{2}$ & $\beta$ & $\mathrm{t}$ & $\mathrm{p}$ \\
\hline Deklarowany czas użytkowania smartfona & \multirow{13}{*}{0,68} & \multirow{13}{*}{0,46} & 0,222 & 3,511 & 0,001 \\
\hline Realny czas użytkowania smartfona & & & 0,192 & 3,092 & 0,002 \\
\hline Wsparcie społeczne & & & 0,447 & 0,551 & 0,582 \\
\hline Wsparcie emocjonalne & & & $-0,273$ & $-1,205$ & 0,230 \\
\hline Wsparcie instrumentalne & & & $-0,031$ & $-0,107$ & 0,915 \\
\hline Zapotrzebowanie na wsparcie & & & 0,178 & 0,704 & 0,482 \\
\hline Poszukiwanie wsparcia & & & $-0,019$ & $-0,058$ & 0,954 \\
\hline Zdrowie fizyczne & & & 0,134 & 1,742 & 0,083 \\
\hline Samopoczucie psychiczne & & & $-0,147$ & $-1,803$ & 0,073 \\
\hline Niezależność i relacje z rodzicami & & & $-0,070$ & $-1,004$ & 0,317 \\
\hline Rówieśnicy i wsparcie społeczne & & & 0,212 & 3,012 & 0,003 \\
\hline Środowisko szkolne i nauka & & & $-0,146$ & $-2,090$ & 0,038 \\
\hline (Stała) & & & & 8,429 & 0,000 \\
\hline
\end{tabular}

Źródło: opracowanie własne. 
Na podstawie wyników analizy można stwierdzić, że testowany model okazał się istotny statystycznie $(\mathrm{F}=11,70, \mathrm{p}<0,01)$. Zmienne w 46\% wyjaśniają wariancję uzależnienia od smartfona. Istotne statystycznie okazały się: deklarowany i realny czas użytkowania smartfona, rówieśnicy i wsparcie społeczne oraz środowisko szkolne i nauka. Na podstawie wartości współczynnika $\beta$ można stwierdzić, że dłuższy czas, zarówno deklarowany jak i realny, spędzany przy smartfonie oraz wyższe poczucie otrzymywanego wsparcia, dobre relacje z rówieśnikami, a także gorsze samopoczucie w szkole i niższe oceny będą istotnymi predyktorami wyższego wskaźnika fonoholizmu. Spośród analizowanych zmiennych najsilniejszymi predyktorami są czas deklarowany $(\beta=0,22)$ oraz wsparcie społeczne i relacje $\mathrm{z}$ rówieśnikami $(\beta=0,21)$.

\section{Omówienie wyników}

Wyniki badań przedstawione w tej pracy wskazują na związek uzależnienia od telefonu z zapotrzebowaniem i poszukiwaniem wsparcia społecznego. Wraz ze wzrostem czasu spędzanego przy urządzeniu odnotowano również nieduży wzrost deklarowanego otrzymywanego wsparcia oraz samopoczucia emocjonalnego. Można sformułować więc wniosek, że osoby aktywne społecznie będą przejawiały również wyższą aktywność w kontaktach cyfrowych. Poszukiwanie wsparcia online jest dziś popularne w grupie wiekowej adolescentów i, jak wskazują wyniki, są oni zadowoleni z otrzymanego wsparcia. Ze względu na intensywność ich relacji w sieci należałoby zwrócić ich uwagę na bezpieczeństwo takich kontaktów oraz wskazać im wartościowe przestrzenie (fora dotyczące ich zainteresowań oraz portale poszerzające ich wiedzę czy umiejętności), w których mogliby się realizować. W badaniach światowych widoczna jest znaczna przewaga „czarnych wizji” na temat użytkowania nowych mediów przez dzieci i młodzież. Istnieje więc silna potrzeba prowadzenia dalszych badań w kierunku podwyższenia jakości ich działań w świecie cyfrowym oraz pozytywnych stron wykorzystywania współczesnych narzędzi technologicznych.

Pojawiają się jednocześnie nowe programy uczące właściwego korzystania z technologii oraz rozwijające kompetencje cyfrowe. Przykładem mogą być zajęcia z programowania i kodowania w placówkach oświatowych oraz szkolenia dla specjalistów zorientowane na wykształcanie prawidłowych postaw w korzystaniu z technologii, gier, kultury cyfrowej (Rozporządzenie Ministra Edukacji Narodowej z 14 lutego 2017 r. w sprawie podstawy programowej wychowania przedszkolnego oraz podstawy programowej kształcenia ogólnego dla szkoły podstawowej).

Co interesujące, ani silniejsze uzależnienie od telefonu, ani dłuższy czas spędzany z nim nie wiązał się z gorszym samopoczuciem fizycznym czy psychicznym. Może to wynikać z wieku badanych, którzy nie odczuwają jeszcze długofalowych skutków obciążenia organizmu. Daje to jednak nadzieję, że kształtowanie prawidłowych 
nawyków może niemal całkowicie uchronić ich od negatywnych efektów zdrowotnych obcowania $\mathrm{z}$ technologią. Pojawia się więc nowe wyzwanie, jakim jest analiza wiedzy młodzieży na temat zapobiegania im i przygotowanie odpowiednich programów profilaktycznych. Ważne jest również wspieranie prawidłowych postaw, które już teraz mogą znajdować się w ich zasobach, wynikających ze świadomego korzystania, autoobserwacji czy wzorców płynących środowiska rówieśniczego i rodzinnego.

Mniej optymistyczne są wyniki pokazujące, że młodzież zdecydowanie przeszacowuje swój czas spędzany w sieci, gdyż średnio spędza przed ekranem około $2 \mathrm{~h} 30 \mathrm{~min}$ mniej, niż podaje. Wynik taki może wiązać się z przeciążeniem informacyjnym oraz wielowątkowym funkcjonowaniem w sieci. Poprzednie pokolenia raczej skupiały się na wykonywaniu jednej czynności w danym momencie. W przypadku współczesnej młodzieży jednoczesne odpowiadanie na wiadomości od kilku, a nawet kilkunastu osób, przeglądanie stron internetowych, zdjęć i portali społecznościowych daje iluzję „zmieszczenia dnia w godzinę”. Czują oni, że ich czas w telefonie jest do tego stopnia przeładowany, że wydaje się dłuższy niż w rzeczywistości.

Realny czas korzystania z telefonu badany za pomocą aplikacji wykazywał niższą korelację z uzależnieniem od urządzenia niż czas deklarowany. Analiza regresji również wykazała, że czas deklarowany jest jego lepszym predyktorem. Być może wynika to $\mathrm{z}$ faktu, że obie zmienne mierzone są w sposób deklaratywny. Poczucie spędzania większej ilości czasu niż w rzeczywistości będzie prawdopodobnie przekładało się na wyższe poczucie zmęczenia technologią i zaniedbywania innych przestrzeni życia. Nie przekreśla to jednak dalszych badań w obrębie tej problematyki. Względem ogólnych założeń metodologicznych stosowanych w naukach społecznych obie zmienne wykazały wysoki związek z uzależnieniem. Mierzenie jedynie deklaratywnej wartości czasu spędzanego na korzystaniu z technologii może zaciemniać obraz realnej rzeczywistości i „demonizować” stopień „przyklejenia” młodzieży do telefonu. Jednocześnie w przypadku występowania chorób związanych z obciążeniem organizmu przez nadmierne używanie tego typu urządzeń zmienna czasu realnego będzie bardziej wymiernym wskaźnikiem niż wyłącznie deklaratywny czas. Okazuje się również, że badania wykazujące różnice w czasie korzystania z telefonu ze względu na płeć mogą bazować jedynie na subiektywnych odczuciach użytkowników, ponieważ realny pomiar nie wykazuje takich różnic. Interesującą obserwacją jest fakt, że różnica między realnym a deklaratywnym czasem w przypadku dziewcząt jest trzy razy wyższa niż chłopców. Jednocześnie ich wynik w skali fonoholizmu również jest nieco wyższy, choć w znacznie mniejszym stopniu. Pojawia się więc pytanie, z czego wynika tak silne przeszacowanie czasu u dziewcząt?

Można zaobserwować również, że wraz ze wzrostem problemowego użytkowania nowych mediów obniżone stają się osiągnięcia w szkole i samopoczucie z nią związane. Mniej niż 6\% uczniów wykorzystuje urządzenie do nauki, zdecydowana większość korzysta z niego wyłącznie dla przyjemności. W zestawieniu z danymi 
dotyczącymi używania telefonów w szkole niesie to za sobą ogromne ryzyko występowania problemów z koncentracją i niższymi wynikami w nauce u osób spędzających dużo czasu z telefonem. Współczesna szkoła stara się nadążyć za zmianami technologicznymi, wprowadzając do klas pomoce cyfrowe, takie jak tablice multimedialne, elektroniczne dzienniki czy kontakt online z nauczycielami, zarówno dla ucznia, jak i rodzica. Być może wykorzystanie w większym zakresie narzędzia znajdującego się już w dłoni ucznia jako pomocy szkolnej przybliżyłoby cyfrowy świat nastolatka do tradycyjnego modelu polskiej szkoły, co mogłoby skutkować większym zaangażowaniem ze strony młodego człowieka.

W tym samym czasie może dochodzić do realizacji potrzeb kulturalnych oraz pozytywnego korzystania z technologii, gier, kultury popularnej w sposób związany $\mathrm{z}$ realizacją potrzeb, rozwojem zainteresowań. Na użytkowników nowych mediów działać może mimowolne uczenie się (Wierzchoń 2009) - taka forma uczenia, którą niekoniecznie dostrzegają nawet sami odbiorcy kultury. Grając, oglądając seriale, wiadomości, tworząc własne materiały (np. filmy na platformę YouTube), adolescenci mimowolnie wchodzą przecież w sytuacje rozwojowe.

Najważniejsze wnioski z przeprowadzonych badań:

- najsilniejszym predyktorem uzależnienia od smartfona jest deklaratywny, nie zaś rzeczywisty czas jego użytkowania;

- młodzież znacznie przeszacowuje swój czas spędzany przed ekranem. Dziewczęta zawyżają go średnio trzy razy bardziej niż chłopcy;

- wraz ze wzrostem uzależnienia znacząco rośnie poszukiwanie i zapotrzebowanie na wsparcie społeczne;

- istnieje związek pomiędzy wyższym deklarowanym czasem i problematycznym użytkowaniem nowych mediów a słabszymi wynikami w nauce i obniżonym samopoczuciem w szkole;

- uzależnienie od telefonu wykazuje niewielki związek z relacjami z rodzicami, brak jest również związku z samopoczuciem fizycznym;

- technologia może być wykorzystywana jako narzędzie wspomagające realizację indywidualnych potrzeb użytkowników;

- wymagane jest tworzenie nowych, adekwatnych zajęć dla specjalistów, dzieci, nastolatków i rodziców, których celem są działania profilaktyczne i skupiające się na zdrowym korzystaniu z technologii, w celu zwiększenia jakości życia człowieka oraz zmniejszenia ryzyka uzależnienia.

Wnioski z powyższej pracy mogą być podstawą do zaprojektowania pogłębionej analizy tematu. Replikacja badań $\mathrm{w}$ innych grupach wiekowych dałaby również szerszy obraz funkcjonowania młodzieży w przestrzeni online. Szczególnie ciekawe wydają się hipotezy dotyczące czasu spędzanego przez młodzież na korzystaniu z urządzeń cyfrowych. Badania na większej grupie pokazałyby lepszą skalę zjawiska i mogłyby być inspiracją do próby wyjaśnienia fenomenu przeszacowywania swoich wyników. 


\section{Literatura}

American Psychiatric Association, 2013, Diagnostic and statistical manual of mental disorders, Washington, DC: American Psychiatric Association.

Dębski M., 2017, Nałogowe korzystanie z telefonów komórkowych. Szczegółowa charakterystyka zjawiska fonoholizmu w Polsce. Raport z badań, Gdynia: Fundacja Dbam o Mój Z@sięg, https://dbamomojzasieg.com/pobierz-raport/ [dostęp: 11.05.2018].

Gausby A., 2015, Attention spans. Consumer Insights, Microsoft Canada, https://pl.scribd.com/ document/265348695/Microsoft-Attention-Spans-Research-Report [dostęp: 11.05.2018].

Gross E.F., Juvonen J., Gable S.L., 2002, Internet use and well-being in adolescence, „Journal of Social Issues" vol. 58, no. 1.

Filiciak M., Danielewicz M., Halawa M., Mazurek P., Nowotny A., 2010, Młodzi i media. Nowe media a uczestnictwo w kulturze. Raport Centrum Badań nad Kulturq Popularna SWPS, Warszawa: Centrum Badań nad Kulturą Popularną SWPS.

Hansraj K.K., 2014, Assessment of stresses in the cervical spine caused by posture and position of the head, „Surgical Technology International” vol. 25.

Jarczyńska J. (red.), 2014, Uzależnienia behawioralne i zachowania problemowe młodzieży. Teoria, diagnoza, profilaktyka, terapia, Bydgoszcz: Wydawnictwo Uniwersytetu Kazimierza Wielkiego.

Kraut R., Kiesler S., Boneva B., Cummings J., Helgeson V., Crawford A., 2002, Internet paradox revisited, „Journal of Social Issues” vol. 58, no. 1.

Kraut R., Patterson M., Lundmark V., Kiesler S., Mukhopadhyay T., Scherlis W., 1998, Internet paradox: A social technology that reduces social involvement and psychological well-being?, „American Psychologist” vol. 53, iss. 9.

Ledzińska M., 2002, Stres informacyjny - sposoby radzenia sobie i przeciwdziałania [w:] Konteksty stresu psychologicznego, red. I. Heszen-Niejodek, J. Matusiak, Katowice: Wydawnictwo Uniwersytetu Śląskiego.

Levinson P., 2006, Telefon komórkowy. Jak zmienit świat najbardziej mobilny ze środków komunikacji, tłum. H. Jankowska, Warszawa: Wydawnictwo Muza.

Łuszczyńska A., Kowalska M., Mazurkiewicz M., Schwarzer R., 2006, Berlińskie Skale Wsparcia Społecznego (BSSS). Wyniki wstępnych badań nad adaptacją skal i ich własnościami psychometrycznymi, „Studia Psychologiczne” z. 3, t. 44.

Mazur J., Małkowska-Szkutnik A., Dzielska A., Tabak I., 2008, Polska wersja kwestionariuszy do badania jakości życia związanej ze zdrowiem dzieci i młodzieży (KIDSCREEN), Warszawa: Instytut Matki i Dziecka.

Park J., Kim J., Kim J., Kim K., Kim N., Choi I., Lee S., Yim J., 2015, The effects of heavy smartphone use on the cervical angle, pain threshold of neck muscles and depression, „Advanced Science and Technology Letters” vol. 91.

Pawłowska B., Potembska E., 2011, Objawy zagrożenia uzależnieniem i uzależnienia od Internetu mierzonego Kwestionariuszem do Badania Uzależnienia od Internetu, autorstwa Pawłowskiej i Potembskiej u młodzieży polskiej w wieku od 13 do 24 lat, „Current Problems of Psychiatry" vol. 12, iss. 4.

Prensky M., 2001, Digital natives, digital immigrants, „On the Horizon” vol. 9, no. 5.

Prensky M., 2012, From Digital Natives to Digital Wisdom: Hopeful Essays for 21st Century Learning, Thousand Oaks: Sage Publications Inc. 
Radziwiłłowicz W., Dębski M., Kozłowska-Frąk A., 2018, Pokolenie always on. Funkcjonowanie emocjonalno-społeczne młodzieży problemowo korzystajacej z nowych mediów [w:] Depresja: wybrane aspekty żywieniowe, psychologiczne i humanistyczne, red. M. Brodnicki, A. Jarmołowska, F. Makurat, A. Bracki, Gdańsk-Kijów: Talkom.

Robitail S., Simeoni M.C., Erhart M., Ravens-Sieberer U., Bruil J., Auquier P., Group E.K., 2006, Validation of the European proxy KIDSCREEN-52 pilot test health-related quality of life questionnaire: first results, „Journal of Adolescent Health” vol. 39, iss. 4.

Rozporządzenie Ministra Edukacji Narodowej z dnia 14 lutego 2017 r. w sprawie podstawy programowej wychowania przedszkolnego oraz podstawy programowej kształcenia ogólnego dla szkoły podstawowej, w tym dla uczniów z niepełnosprawnością intelektualną w stopniu umiarkowanym lub znacznym, kształcenia ogólnego dla branżowej szkoły I stopnia, kształcenia ogólnego dla szkoły specjalnej przysposabiającej do pracy oraz kształcenia ogólnego dla szkoły policealnej (Dz. U., poz 356).

Rywczyńska A., 2012, Wstęp [w:] Nadmierne korzystanie z komputera i Internetu przez dzieci i młodzież, Warszawa: Polskie Centrum Programu Safer Internet.

Sęk H., Cieślak R., 2004, Wsparcie społeczne - sposoby definiowania, rodzaje i źródła wsparcia, wybrane koncepcje teoretyczne [w:] Wsparcie społeczne, stres i zdrowie, red. H. Sęk, R. Cieślak, Warszawa: Wydawnictwo Naukowe PWN.

Sharan D., Ajeesh P.S., 2012, Risk factors and clinical features of text message injuries, „Work” vol. 41 (suppl. 1).

Skarżyńska K., Henne K., 2005, Internet, kapitał społeczny, szczęście. Kto i dlaczego korzysta $z$ Internetu?, „Kolokwia Psychologiczne” nr 13.

Small G., Vorgan G., 2011, iMózg. Jak przetrwać technologiczna przemianę współczesnej umysłowości, tłum. S. Borg, Poznań: Vesper.

Spitzer M., 2013, Cyfrowa demencja. W jaki sposób pozbawiamy rozumu siebie i swoje dzieci, tłum. A. Lipiński, Słupsk: Wydawnictwo Dobra Literatura.

WHOQOL Group, 1995, The World Health Organization Quality of Life assessment (WHOQOL): Position Paper from the World Health Organization, „Social Science and Medicine" vol. 41, iss. 10.

Wierzchoń M., 2009, Koszty poznawcze uczenia mimowolnego, Kraków: Wydawnictwo Uniwersytetu Jagiellońskiego.

Woronowicz B.T., 2009, Uzależnienia. Geneza, terapia, powrót do zdrowia, Warszawa: Media Rodzina.

Yang S.Y., Chen M.D., Huang Y.C., Lin C.Y., Chang J.H., 2017, Association Between Smartphone Use and Musculoskeletal Discomfort in Adolescent Students, „Journal of community health" vol. 42 , iss. 3 .

Young K., Rodgers R.C., 1998, The Relationship Between Depression and Internet Addiction, „CyberPsychology \& Behavior” vol. 1, iss. 1. 


\section{Streszczenie}

Celem niniejszej pracy jest analiza związku pomiędzy problemowym używaniem telefonu komórkowego przez młodzież a wsparciem społecznym i jakością życia, a także próba odpowiedzi na pytanie, czy młodzież trafnie przewiduje czas spędzony przed ekranem urządzenia. W badaniu udział wzięły 453 osoby w wieku 16-19 lat. Wykorzystano ankietę fonoholizmu (autorstwa Macieja Dębskiego, Wioletty Radziwiłłowicz, Agnieszki Kozłowskiej-Frąk) Berlińskie Skale Wsparcia Społecznego, kwestionariusz KIDSCREEN-27 oraz aplikację QualityTime. Wyniki badań wskazują na znaczne przeszacowywanie czasu spędzanego przez młodzież z telefonem i fakt, że to właśnie czas deklarowany jest najsilniejszym predyktorem fonoholizmu. Widoczny jest również związek nadmiernego korzystania ze smartfona z poszukiwaniem i zapotrzebowaniem na wsparcie społeczne. Telefon okazuje się ważnym narzędziem służącym do utrzymywania kontaktów rówieśniczych. Osoby deklarujące większe problemy w zakresie korzystania z telefonu zgłaszają również słabsze wyniki w nauce i gorsze samopoczucie w szkole. Nie zaobserwowano różnic w zakresie samopoczucia fizycznego.

\section{Słowa kluczowe}

technologia, nowe media, młodziė̇, wsparcie społeczne, jakość życia

\section{Summary}

\section{"Always on" generation - psychological and social functioning of teenage technology media users}

The aim of this study is to examine the relationship between the problematic use of a mobile phone by young people, social support and quality of life, as well as an attempt to answer the question whether young people accurately predict the time spent in front of the phone screen. The study was attended by 453 people aged 16-19. In order to examin participants, a phonholism questionnaire, the Berlin Social Support Scales, KIDSCREEN-27 questionnaire and The QualityTime application was used. The results of the research indicate a significant overestimation of the time spent by young people with the telephones. However, the declared time was a stronger predictor of phonholism. There is also a visible connection of excessive use of a smartphone with the search and demand for social support. The phone turns out to be a powerful tool for maintaining peer contacts. People who report more problems with using the telephone also report weaker results in learning and discomfort at school. There were no differences in physical well-being.

\section{Keywords}

technology, new media, youth, social support, quality of life 